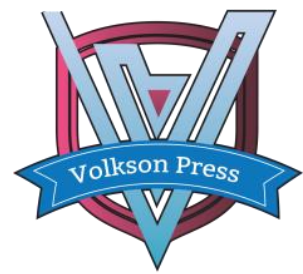

\title{
Research on establishment and talent training mode of management accounting information system based on tax planning
}

\author{
CuiShufen ${ }^{1}$, SunLiHeng
}

Wuhan Donghu college, Wuhan, China,430032Email: 71101875@qq.com Email: $171101875 @ q q . c o m{ }^{1}$, 790124653@qq.com ${ }^{2}$

This is an open access article distributed under the Creative Commons Attribution License, which permits unrestricted use, distribution, and reproduction in any medium, provided the original work is properly cited.

\section{ARTICLE DETAILS}

\section{Article History:}

Received 02 october 2017

Accepted 06 october 2017

Available online 11 october 2017

Keywords:

tax cuts, management accounting information system, Personnel

training mode.

\section{ABSTRACT}

Enterprises enjoy various tax preferential policies, restricted by policies, procedures, talents and other factors, through the tax preferential policies to integrate the management accounting information system, realtime update the talent training program and course content, training students in the current policy and enterprise practical operating procedures, familiar with the process of tax planning, to complete the process of identification and implementation, to cultivate the shortage of small and medium-sized enterprises management accounting talent target.
1. The enterprise badly needs the tax planning personnel and the finance profession talented person employment difficult contradiction prominent.

With the construction and development of tax system " golden tax iii project ", the concept of technology tax and service tax promotion has become the requirements of the new era, and information management system in the tax service work more and more prominent, with the complexity of tax preferential policies increasing, enterprises enjoy concessions more and more difficult, related management accounting personnel shortage. At present, the management accounting personnel training mode teaching materials are outdated, teachers can not meet the needs, the curriculum content is divorced from the reality. Establishing the management accounting information system based on tax preferential planning updating the talent training mode, become the preferred mode to meet the enterprise demand and solve the employment of college students.

1.1 the complexity of tax policy, high requirements for enterprise financial accounting, improve the enterprise tax compliance cost.

The present tax system is more complicated. Many tax provisions in the provisions of the principle of bias, and enterprises in real management according to regulatory documents and a series of complex tax provisions, easy to make enterprises understand and grasp the tax law.

Since the operation of the enterprise is always changing with the development, the last indicator as the new annual income tax exemption standard, is not fully in line with the actual situation. This series of conditions led to the lack of full implementation of tax preferential policies.

\section{2 excessive requirements for financial accounting.}

A wide range of declared materials became the first obstacle to small and micro businesses. Small and micro enterprises need to fill in a series of reports, such as the filing table of enterprise income tax, monthly payroll, social security payment record form, financial accounting statements, labor dispatch agreement, labor contract and other materials. The increase in the withholding of personal income tax vouchers, the industrial directory corresponding to the industrial description. The influence of the individual business ability of the tax officers or the enterprise's own business plan and other reasons lead to the failure to perform the filing procedures, so as to make the preferential policies ineffective, or to abandon the preferential policies.

1.3 The actual burden of small and micro enterprises
First, China's economic institutions, prominent state-owned enterprises and foreign capital enterprises develop faster, thanks to the international preferential policy support. But the small and micro enterprises preferential policies, but the requirements to achieve preferential conditions have a standard, the ability of small enterprises is often difficult to achieve, make many preferential policies, small and micro enterprises actually difficult to enjoy, the actual tax law is higher than nominal tax. Second, because small and micro enterprises operating small scale, income and pre-tax deductions are not many projects, profit is meager, the actual tax on the relative small and small enterprises ability to appear heavier. Third, the social service environment pressure of small and micro enterprises, small and micro enterprises basically belong to the county, township level government or town street offices, or urban streets and other grass-roots organizations, but at present our county, township level of relatively difficult financial, street management level is limited, small and micro enterprises become the focus object of charge, apportion, fundraising, even more unbearable.

2. The target of talent training mode of management accounting information system

Bring the industry tax preferential policy into the training course of the management accounting personnel training, by establishing the management accounting information system, establish comprehensive solution platform, greatly reduce the tax cost of small and micro enterprises, so that small and micro enterprises can develop faster, more stable and healthy in life.

The management accounting information system can simplify the preferential policy and the collection process, so that the preferential policy is simple and easy to operate. To enhance the income tax incentives to the technological innovation of small and micro enterprises.

Tmely give the enterprise risk prompt by management accounting information system

Because the enterprise is not comprehensive to the tax law policy, especially the high technology concessions, high qualification threshold, many policy conditions, complex financial processing, it is difficult to judge the application of preferential policies. The management accounting information system makes the risk prompt, guides the enterprise correctly applies the relevant regulations, timely guard against the tax risk.

Cultivate the talents of tax planning urgently needed by enterprises, solve the enterprise demand and solve the employment problem of finance and 


\section{References}

\section{Basic functions and models of the management accounting information system}

The management accounting information system includes the enterprise preferential policy business processing framework, tax risk and planning application logic structure, talent training application technology architecture 3 architecture. The business structure mainly describes the division of various tax preferential business modules of the enterprise; The application logic architecture mainly describes the functions of various tax planning sub-systems and the user interface The application technology framework mainly describes the management accounting personnel training platform / two engine / three-tier structure. To construct a complete design idea of tax preference recognition, declaration, account and report generation, to design and implement the tax reduction information management system, to complete the double goal of tax planning and talent training.

\section{Conclusion}

At present, the economy enters the new normal, the enterprise tax preferential policy has the important promotion function to the enterprise development, but the tax compliance cost is higher, the policy complex threshold is high, the process is complicated, the enterprise related professional personnel lacks. The management accounting information system based on tax preferential can integrate the tax preferential policy and the management accounting personnel training scheme, at the same time to solve the enterprise talent needs and the difficult problem of university personnel employment, is an effective solution of economic development and education reform.
[1] Cui Shufen, Sun Liheng. Influence of "The Business Tax to VAT Transformation Reform" on Enterprise Tax Burden and Financial Countermeasures [J]. Finance and Accounting Monthly. 2014(09)

[2] Hu Donglan, Chen fan. Review of Structural Tax Reduction in China [J]. Economic Review.2013(03)

[3] Liu Caixia. Analysis of Tax Burden of Agricultural electronic commerce enterprise in China and Suggestions [J]. Finance and Accounting Monthly. 2013(04)

[4] Zhang Ying. China Review of the Structural Tax Reduction Policy Following the International Financial Crisis. China \&World Economy. 2010

[5] Rogoff. K. S. Equilibrium Political Budget Cycles. 1990

[6] Jin Qinglei. Crime of Falsely Making Out Specialized Value Added Tax Receipts. Legal and Economic (MID). 2014 (01)

[7] Liang Jian. Study on Several Problems of the Crime of Falsely Making Out Specialized Value Added Tax Receipts[J]. Journal of Beijing University of Science and Technology (Social Science Edition). 2003(01)

Label:This project is supported by the sixth batch accounting research ( focus ) project of Hubei institute of accounting science, Hubei institute of finance [ 2016 ] 26; Supported by Hubei province education planning project in 2016. 